\title{
Plio-Pleistocene \\ Paleoceanography in the North Atlantic
}

\section{by David B. Scott and Kenneth G. Miller}

Modern concepts of climatic forcing and oceanic reponse are now being extended back beyond the Late Pleistocene, and one major focus is on Pliocene-Early Pleistocene marine sections drilled in the deep oceans. The study of piston cores has enabled global sea surface temperatures and changes in ice volumes to be reconstructed on the basis of fossil distributions and oxygen isotope ratios. Glacialinterglacial cycles detected are now explained in terms of Milankovitch orbital variations. Major advances have also been made in studying the circulation of the deep oceans during the Pleistocene, but its effect on the development of climatic regimes is still in doubt. (Ed.)

\section{Reconstructing the Climate}

Late Pleistocene climatic fluctuations and oceanic responses have been linked directly to astronomical forcing. Recent workers have extended these studies to include the nature of climatic foreing and oceanic response in the early Pleistocene and older epochs. One approach to the fundamental question of how climatic and oceanic changes differed between the late Pleistocene and the early Pleistocene-Pliocene focuses on sedimentary sections recently obtained in the North Atlantic.

With the formation of CLIMAP (Climate Long Range Investigation and Predictions Program) in the early 1970s, paleoceanography evolved from isolated studies to coor-

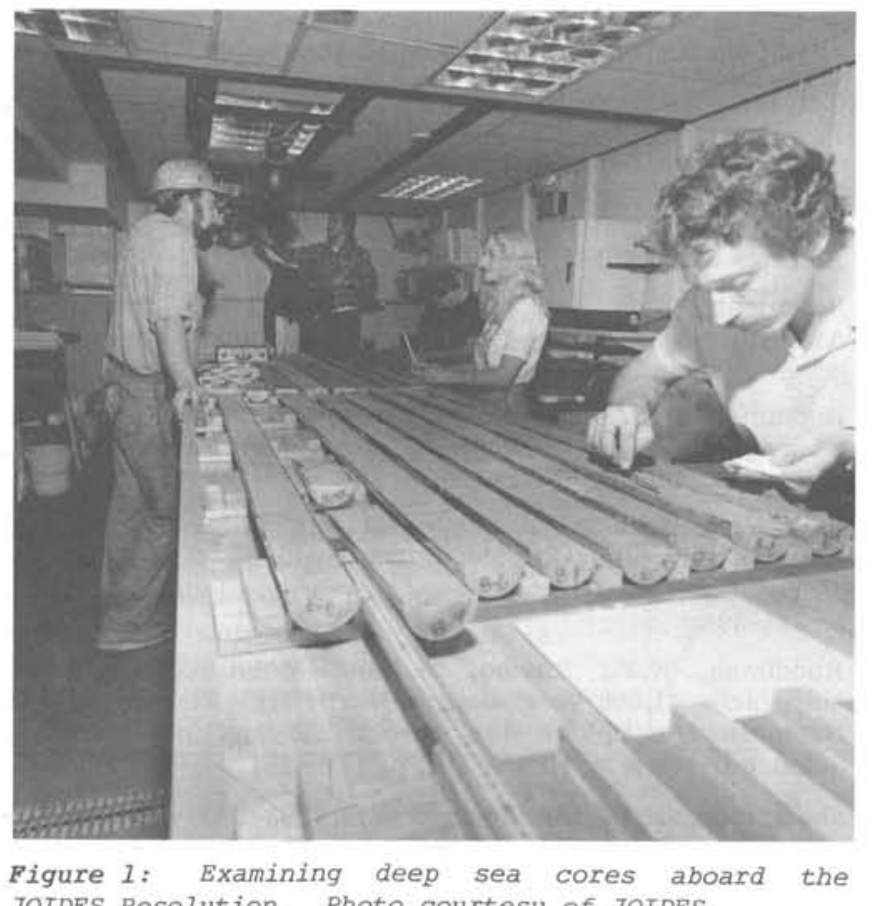

dinated efforts around the world, involving many individuals and institutions. CLIMAP developed a standardized routine for reconstructing paleoceanographic signals based upon modern oceanographic and floral/faunal data, extending modern calibrations "downcore" into the late Pleistocene. Late Pleistocene reconstructions under CLIMAP relied upon piston core sections, which typically recovered only the youngest sediments.

Beginning in the late 1960s, the Deep Sea Drilling Project (DSDP) and its successor, the Ocean Drilling Project (ODP), recovered relatively complete Quaternary and Tertiary sections. However, the rotary drilling process often disturbed the soft layers of the uppermost sediments, limiting high-resolution (10,000-100,000 years) climatic studies. Development of the hydraulic piston core in 1979 allowed collection of undisturbed samples from non-consolidated sediments. These long, undisturbed eores have allowed the techniques applied to late Pleistocene climates to be used for reconstructing the older record.

Studies of late Pleistocene piston cores (Figs. 1, 2) allowed reconstructions of global sea-surface temperature changes that occurred between glacial (e.g. 18,000 yBP), interglacial (e.g. 125,000 yBP), and modern oceans (McIntyre et al., 1976). These studies relied heavily upon empirical correlations of temperature with the distribution of flora and fauna in order to reconstruct surface-ocean temperatures.

Studies of stable oxygen isotope ratios in foraminifera comprised a key element in these reconstructions, recording ice volume and temperature changes. The oxygen isotope record is a powerful stratigraphic tool that constitutes a climatic and stratigraphic standard, allowing comparisons of oceanic and terrestrial records. Twenty-two Pleistocene stages have been delineated and correlated using ${ }^{18} \mathrm{O}$ through the deep sea. Oxygen isotope changes point to two distinct climatic intervals: the late Pleistocene (ca. 900,000 $\mathrm{yBP}$ to the present) and the late Pliocene-early Pleistocene $(2,400,000-900,000 \mathrm{yBP})$. The late Pleistocene ice-volume fluctuations were greater than those of the Pliocene-early Pleistocene.

\section{Late Pleistocene Glacial Cycles}

The most exciting aspect of this work is the documentation that the late Pleistocene glacial-interglacial cycles were controlled by astronomical foreing, and that vilankovitch orbital perturbations were pacemakers for the waxing and waning of late Pleistocene ice sheets. Three Milankovitch periods (Hays et al., 1976) dominated late Pleistocene climate: 100,000 years (eccentricity of earth's orbit), 41,000 years (tilt of earth's axis), and 21,000 years (precession of the equinoxes). During the start of the late Pleistocene (until about $900,000-700,000 \mathrm{yBP}$ ), the 100,000 year period was dominant. However, recent studies suggest that the early Pleistocene to late Pliocene climate was dominated by the 4l,000 year period (Ruddiman et al., 1986).

This tantalizing observation suggests that the earth's climatic system responded to astronomical forcing in a different manner before $900,000 \mathrm{yBP}$, and that oceanic 
responses may have differed. In addition, 180 studies suggest that another major climatic step occurred at $2,400,000$ yBP (Shackleton et al., 1984); this step is believed to reflect a major phase of northern hemisphere ice growth. This raises the intriguing and as yet unanswered question of the tempo of climatic change even before the development of large northern hemisphere ice sheets.

\section{Deep Ocean Circulation}

In addition to mapping of surface ocean response to climatic change, recent advances have been made in reconstructing Pleistocene deep ocean circulation. Studies of changes in benthic foraminiferal assemblages, comparisons of benthic foraminiferal carbon isotope records (e.g. Curry and Lohmann, 1983), and measurements of cadmium in benthic foraminifera shells have shown that glacial patterns of deep-water circulation were dramatically different from interglacial patterns.

The reconstruction of deep-water changes has raised provocative questions about their role in glacial-interglacial ehanges. Broecker and others (1985) suggest that bottom water production in the North Atlantic provides a considerable amount of atmospheric heat to the northern hemisphere. If this production if reduced, as it is during glacial intervals, then that hemisphere will lose a signficant amount of heat, regardless of insolation values controlled by orbital forcing. Hence the variations in bottom water have implieations for climate as well as deep-water circulation patterns. Details of deep-water changes during the late Pleistocene are only now being worked out. The question of their role in the different elimatic regimes of the late Pleistocene and early Pleistocene-Pliocene still remains.

\section{Commentary}

Major contributions to the story of how events unfolded in the North Atlantic during glacial-interglacial cycles have been made by W.R. Ruddiman and A. MeIntyre (1981a, b, 1984, 1986). Together with other CLIVIAP investigators, they have provided models of polar front movement across the last glacial/interglaical boundary, and more recently they have been investigating the Milankoviteh orbital eycles, using a technique called spectral analysis, under the SPECMAP program, which succeeded CLIMAP. The former uses a sophisticated computer program to synthesize a series of timed oceanic events into frequency diagrams. Ruddiman and Mcintyre have now been able to show that the frequencies of events occur remarkably close to those predicted by Milankoviteh for the various orbital parameters.

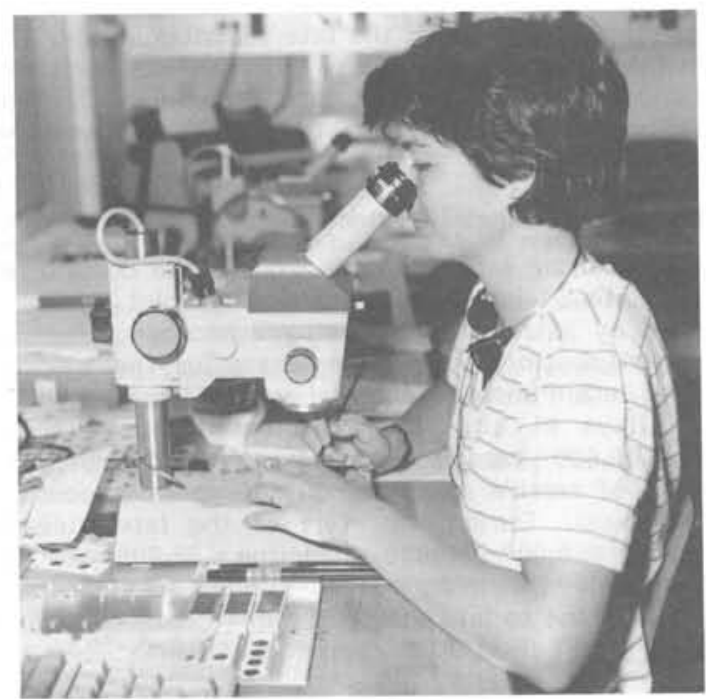

Figure 2: Studying samples from the deep ocean floor. JOIDES photo.
The detailed models produced by CLIMAP are now being extended back in time beyond the Late Pleistocene, using data gathered by DSDP and ODP drilling, to understand changing climate-system response to astronomical forcing throughout the entire Quaternary Period.

INQUA '87. Special Session 33: Paleoceanography of the North Atlantic: Late Pleistocene vs Pliocene. Organizers: D.B. Scott (Canada) and $K$. Miller (U.S.A.).

Dr. D. B. Seott teaches marine geology at the Department of Geology, Dalhousie University (Halifax, N.S. Canada B3H 3J5). His research interests include the distribution and taxonomy of Quaternary benthonic foraminifera, glacial triggering, Quaternary sea levels and oxygen isotopes applied to paleoecology.

Dr. K. G. Miller is a researcher at Lamont-Doherty Geological Observatory (Palisades, New York 10964, U.S.A.), where he works on foraminiferal biostratigraphy, paleoecology, paleobiogeography, seismic stratigraphy, Cenozoic sea-level and paleoceanographic changes.

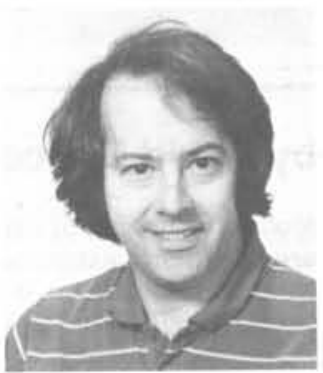

\section{References}

Broecker, W.S., Peteet, D.M. and Rind, D., 1985. Does the ocean-atmosphere system have more than one stable mode of operation. Nature, v. 315 , no. 6014, p. 21-26.

Curry, W.B. and Lohmann, G.P., 1983. Reduced advection into Atlantic Ocean deep eastern basins during last glaciation maximum. Nature, v. 306 , no. 5943 , p. 577-580.

Hays, J.D., Imbrie, J. and Shackleton, N.J., 1976. Variations in the Earth's orbit: pacemaker of the ice ages. Science, v. 194 , no. 4270 , p. $1121-1132$.

MeIntyre, A., Kipp, N.G., Be, A.W.H., Crowley, T., Kellogg, T., Gardner, J.V., Prell, W.L. and Ruddiman, W.F., 1976. Glacial North Atlantic 18000 years ago: a CLIVIAP reconstruction. In: Investigations of Late Quaternary Paleoceanography and Paleoclimatology, Geological Society of America Memoir 145, p. 43-76.

Ruddiman, W.F. and MeIntyre, A., 1981a. The North Atlantic ocean during the last deglaciation. Palaeogeography, Palaeoclimatology, Palaeoecology, v. 35, p. 145-214.

Ruddiman, W.F. and McIntyre, A., 1981b. Oceanic mechanism for amplification of the 23,000 -year ice volume cycle. Science, v. 212, p. 617-627.

Ruddiman, W.F. and MeIntyre, A., 1984. Ice-age thermal response and climatic role of the surface Atlantic Ocean, $40^{\circ} \mathrm{N}$. Geological Society of America Bulletin, v. 94, p. 381-396.

Ruddiman, W.F., Raymo, M. and MeIntyre, A., 1986. Matuyama 41,000-year eycles: North Atlantic Ocean and Northern Hemisphere ice sheets. Earth and Planetary Science Letters, v. 80 , no. 1-2, p. 117-129.

Shackleton, N.J., and many others, 1984. Oxygen isotop $\epsilon$ calibration of the onset of ice-rafting and history of glaciation in the North Atlantic region. Nature, v. 307 , no. 5952 , p. $620-623$. 